\title{
STATE PRACTICE OF ASIAN COUNTRIES IN THE FIELD OF INTERNATIONAL LAW*
}

\author{
INDIA
}

\section{JUDICIAL DECISIONS}

Under international law a merchant ship, upon entering the waters of a State other than the flag State, subjects itself to the jurisdiction of the coastal State as a manifestation of the latter's sovereignty; Admiralty jurisdiction of Indian courts; High Courts in India, as a superior Court of record have inherent jurisdiction over the foreign ship and can order its arrest; The Brussels Conventions on matters of maritime law are to be regarded as the international law or transnational law as rooted in and evolved out of the general principles of national laws and as such can be regarded as part of the common law of India; Effect of Article 372 of the Indian Constitution (according to which Colonial statutes continue to remain in force) on the subsequent growth of the law.

Supreme Court, 26 February 1992

JT 1992 (2) S.C.65**

Dr. T.K. THOMMEN and R.M. SAHAI, JJ.

M.V. ELISABETH \& OTHERS v. HARWAN INVESTMENT \& TRADING PVT. LTD

* Edited by Ko Swan Sik, General Editor

** Courtesy of Dr. T. Kochu Thommen, New Delhi. Not long after receiving Judge Kochu Thommen's contribution the Editors were saddened to hear that Judge Thommen had passed away in his home state of Kerala, India, in December 1993.

Asian Yearbook of International Law, Volume 3 (Ko Swan Sik et al., eds.; 0-7923-2708-X; (C) 1994 Kluwer Academic Publishers; printed in Great Britain), pp. 183-219 
The facts

The Appellant-defendants in "breach of duty" left the port of Marmagao on 8.2.84 and delivered the goods to the consignee in breach of the plaintiff's directions to the contrary, thereby committing conversion of the goods entrusted with them. The Respondent-plaintiff instituted the suit in Andhra Pradesh High Court invoking its admiralty jurisdiction by means of an action in rem. The vessel was arrested when it entered the Port of Vishakhapatnam on 13.4.84 after returning from foreign ports. The defendants moved an application in the High Court raising a preliminary objection to the jurisdiction of that Court. They contended that the plaintiff's suit against a foreign ship owned by a foreign company not having a place of residence or business in India was not liable to be proceeded against on the admiralty side of the High Court by an action in rem in respect of a cause of action alleged to have arisen by reason of a tort or a breach of obligation arising from the carriage of goods from a port in India to a foreign port. Their sole contention on the question of jurisdiction was as regards the lack of admiralty jurisdiction of any Court in Andhra Pradesh or any other State in India to proceed in rem against the ship on the alleged cause of action concerning carriage of goods from an Indian port to a foreign port. The preliminary objection was overruled by the learned Single Judge and his order was confirmed by the learned Judges of the Division Bench.

Counsel for appellants (defendants) argued, inter alia, (1) that the power of the High Court on the admiralty side is contained in and confined to the provisions of the [British] Admiralty Court Act, 1861 (24 \& 25 Victoriae, Ch.10) which were made applicable to India by the Colonial Courts of Admiralty Act, 1890; (2) that the extent of admiralty jurisdiction and the judicial power peculiar to that jurisdiction, as conferred on the Indian High Courts, remained frozen as of the date of the Admiralty Court Act, 1861; (3) that since the only provision of the 1861 Act respecting cargo, i.e. section 6 , is confined to inward cargo, consequently the Indian High Court exercising admiralty jurisdiction has no power to deal with any claim concerning outward cargo.

Counsel for the respondent-plaintiff submitted, inter alia, that what the High Court has stated is based on a realistic appreciation of the need for liberal construction of the statutes so as to support assumption of jurisdiction to render justice where justice is required to be done rather than resorting to a technical or narrow or pedantic construction resulting in a state of helplessness. 
THOMMEN, J:

6. The crucial question for our consideration is, therefore, the dispute about jurisdiction ...

13. In a number of decisions of the Calcutta and Bombay High Courts, the admiralty jurisdiction of the High Courts in India has been historically traced ... The view taken in these decisions is that the admiralty jurisdiction of the High Court in India does not extend beyond the ambit of the provisions of the (English) Admiralty Court Act, 1961 ...

15. This restrictive construction is, in our view, not warranted by the provisions of the Constitution. The fact that the High Court continues to enjoy the same jurisdiction as it had immediately before the commencement of the Constitution, as stated in Article 225, does not mean that a matter which is covered by the Admiralty Court Act, 1861 cannot be otherwise dealt with by the High Court, subject to its own Rules, in exercise of its manifold jurisdiction, which is, unless barred, unlimited. To the extent not barred expressly or by necessary implication, the judicial sovereignty of this country is manifested in the jurisdiction vested in the High Courts as superior courts.

18. It is true that the Colonial statutes continue to remain in force by reason of Article 372 of the Constitution of India, but that does not stultify the growth of law or blinker its vision or fetter its arms. Legislation has always marched behind time, but it is the duty of the Court to expound and fashion the law for the present and the future to meet the ends of justice.

19. We do not accept the reasoning of the High Courts in the decisions cited above on the question of jurisdiction, whatever be the correctness of their decisions on the peculiar facts of those cases in regard to which we express no view. But the narrow view adopted in those decisions on the source and ambit of the admiralty jurisdiction of the High Courts is, in our opinion, not warranted. 
27. Assuming that the admiralty powers of the High Courts in India are limited to what had been derived from the Colonial Courts of Admiralty Act, 1890, that Act, having equated certain Indian High Courts to the High Court of England in regard to admiralty jurisdiction, must be considered to have conferred on the former all such powers which the latter enjoyed in 1890 and thereafter during the period preceding the Indian Independence Act, 1947 ...

65. In tracing the history of admiralty law in India, it is likewise misleading and incorrect to confine it to statutes. Statutes have been codifications of rules of law as developed by usage, practice and custom ...

66. Where statutes are silent and remedy has to be sought by recourse to basic principles, it is the duty of the Court to devise procedural rules by analogy and expediency ...

67. It is likewise within the competence of the appropriate Indian Courts to deal, in accordance with the general principles of maritime law and the applicable provisions of statutory law, with all persons and things found within their jurisdiction. The power of the Court is plenary and unlimited unless it is expressly or by necessary implication curtailed. Absent such curtailment of jurisdiction, all remedies which are available to the courts to administer justice are available to a claimant against a foreign ship and its owner found within the jurisdiction of the concerned High Court. This power of the Court to render justice must necessarily include the power to make interlocutory orders for arrest and attachment before judgment.

68. The High Courts in India are superior courts of record. They have original and appellate jurisdiction. They have inherent and plenary powers. Unless expressly or impliedly barred, and subject to the appellate or discretionary jurisdiction of this Court, the High Courts have unlimited jurisdiction, including the jurisdiction to determine their own powers. (See Naresh Shridhar Mirajkar and Ors. v. State of Maharashtra and Anr., [(1966) 3 SCR 744]. As stated in Halsbury's Laws of England, 4th edition, Vol.10, para 713:

"Prima facie, no matter is deemed to be beyond the jurisdiction of a superior Court unless it is expressly shown to be so, while nothing is within the jurisdiction of an inferior Court unless it is expressly shown on the face of the proceedings that the particular matter is within the cognizance of the particular court." 
73. It is well recognised in international law that a merchant ship, though generally governed by the laws of the flag State, subjects itself to the jurisdiction of a foreign State as it enters its waters. The Geneva Convention on the Territorial Sea and the Contiguous Zone, 1958 and the Law of the Sea Convention, 1982 affirm that the sovereignty of a State extends over its internal and territorial waters. ${ }^{11}$

76. All foreign merchant ships and persons thereon fall under the jurisdiction of a coastal State as they enter its waters. Subject to the right of "innocent passage", the coastal State is free to exercise jurisdiction over such ships in respect of matters the consequences of which extend beyond the ships. Such ships are subject to the local jurisdiction in criminal, civil and administrative matters. This jurisdiction is, however, assumed only when, in the opinion of the local authorities, the peace or tranquillity of the port is disturbed, when strangers to the vessel are involved or when the local authorities are appealed to. Questions which affect only the internal order and economy of the ship are generally left to the authorities of the flag State. Coastal States are entitled to assume jurisdiction in respect of maritime claims against foreign merchant ships lying in their waters. These ships are liable to be arrested and detained for the enforcement of maritime claims. The courts of the country in which a foreign ship has been arrested may determine the cases according to merits, provided they are empowered to do so by the domestic law of the country or in any of the cases recognised by the International Convention relating to the Arrest of Seagoing Ships, Brussels, $1952 .{ }^{12}$ The maritime claims in respect of which the power of arrest is recognised in law include claims relating to damage caused by any ship either in collision or otherwise; claims relating to carriage of goods in any ship whether by charterparty or otherwise, loss of or damage to goods etc. These principles of international law, as generally recognised by nations, leave no doubt that, subject to the local laws regulating the competence of courts, all foreign ships lying within the waters of a State, including waters in ports, harbours, roadsteads, and territorial waters, subject themselves to the jurisdiction of the local authorities in respect of maritime claims and they are liable to be arrested for the enforcement of such claims.

11 See Nagendra Singh, International Maritime Law Conventions, British Shipping Laws, Vols.I to IV.

12 See also the International Conventions for the Unification of Certain Rules relating to Maritime Liens and Mortgages of 10th April, 1926 and May 27 1967). 
79. The Merchant Shipping Act, 1958 contains various provisions to enforce territorial jurisdiction ...

80. The detention of a foreign ship is authorized in terms of sections 443 and $444 \ldots$

82. The Indian Carriage of Goods by Sea Act, 1925 applies to carriage of goods by sea under bills of lading or similar documents of title from a port in India to any other port whether in or outside India. (See section 2) ...

83. The Merchant Shipping Act empowers the concerned High Court to arrest a ship in respect of a substantive right. A right conferred by the Indian Carriage of Goods by Sea Act, 1925 in respect of outward cargo is one of those rights which can be enforced by arrest and detention of the foreign ship in order to found jurisdiction over the vessel and its owners, just as it can be done in respect of inward cargo by reason of the substantive rights conferred by the Admiralty Court Act, 1861 read with the Colonial Courts of Admiralty Act, 1890 , and other rules of law. ... Viewed in this light, and by this reasoning, the Andhra Pradesh High Court, as a successor to the Madras High Court, does not lack admiralty jurisdiction in respect of claims relating to outward cargo.

84. The admiralty jurisdiction of the High Court is dependent on the presence of the foreign ship in Indian waters and founded on the arrest of that ship. This jurisdiction can be assumed by the concerned High Court, whether or not the defendant resides or carries on business, or the cause of action arose wholly or in part, within the local limits of its jurisdiction. Once a foreign ship is arrested within the local limits of the jurisdiction of the High Court, and the owner of the ship has entered appearance and furnished security to the satisfaction of the High Court for the release of the ship, the proceedings continue as a personal action.

85. The Merchant Shipping Act, 1958 provides a detailed code of substantive and procedural rules regulating shipping as an industry and the control exercised over it by the competent authorities. ... Likewise, the substantive rules concerning transport of goods are contained in the Indian Bills of Lading Act, 1856 and the Indian Carriage of Goods by Sea Act, 1925. But the jurisdictional questions concerning arrest of foreign ships for enforcement of claims against the shipowner as a transporter of goods, which in England are regulated by the Supreme Court Act 1981, are in many respects left unregulated by Indian legislation. While the provisions of various international conventions concerning arrest of ships, civil and penal jurisdiction in matters of collision, maritime liens and mortgages etc. have been incorporated 
into the municipal laws of many maritime States, India, as stated above, lags behind them in adopting these unified rules. By reason of this void, doubts about jurisdiction often arise, as in the present case, when substantive rights, such as those recognized by the Carriage of Goods by Sea Act, are sought to be enforced. The remedy lies, apart from enlightened judicial construction, in prompt legislative action to codify and clarify the admiralty laws of this country. This requires thorough research and investigation by a team of experts in admiralty law, comparative law, and public and private international law. Any attempt to codify without such investigation is bound to be futile.

86. ... Although India has not adopted the various Brussels Conventions, the provisions of these Conventions are the result of international unification and development of the maritime laws of the world, and can, therefore, be regarded as the international common law or transnational law rooted in and evolved out of the general principles of national laws, which, in the absence of specific statutory provisions, can be adopted and adapted by courts to supplement and complement national statutes on the subject. In the absence of a general maritime code, these principles aid the courts in filling up the lacunae in the Merchant Shipping Act and other enactments concerning shipping. ...

87. It is important to remember that the Brussels Convention on Arrest of Ships merely restricts or regulates the power of the coastal States and is not intended to confer power which they did not otherwise have as sovereign States. "Arrest" to which the convention refers is detention of a ship to secure a maritime claim, and not seizure of a ship in execution or satisfaction of judgment.

88. The judicial power of this country, which is an aspect of national sovereignty, is vested in the people and is articulated in the provisions of the Constitution and the laws and is exercised by courts empowered to exercise it. It is absurd to confine that power to the provisions of imperial statutes of a bygone age. Access to Court which is an important right vested in every citizen implies the existence of the power of the Court to render justice according to law. Where statute is silent and judicial intervention is required, Courts strive to redress grievances according to what is perceived to be principles of justice, equity and good conscience.

89. In the words of Chief Justice Marshall:

\footnotetext{
"The jurisdiction of courts is a branch of that which is possessed by the nation as an independent sovereign power. The jurisdiction of the nation within its own territory is necessarily exclusive and absolute. It is susceptible of no limitation not imposed by itself ..."
} 
The Schooner Exchange v. M'Faddon \& Ors. US Supreme Court Reports, Cranch 5-9, p. 114, 133 (3 L.ed.287).

90. Admiralty jurisdiction is an essential aspect of judicial sovereignty which under the Constitution and the laws is exercised by the High Court as a superior Court of record administering justice in relation to persons and things within its jurisdiction. Power to enforce claims against foreign ships is an essential attribute of admiralty jurisdiction and it is assumed over such ships while they are within the jurisdiction of the High Court by arresting and detaining them.

91. All persons and things within the waters of a State fall within its jurisdiction unless specifically curtailed or regulated by rules of international law. The power to arrest a foreign vessel, while in the waters of a coastal State, in respect of a maritime claim, wherever arising, is a demonstrable manifestation and an essential attribute of territorial sovereignty. This power is recognized by several international conventions. These conventions contain the unified rules of law drawn from different legal systems. Although many of these conventions have yet to be ratified by India, they embody principles of law recognized by the generality of maritime States, and can therefore be regarded as part of our common law. The want of ratification of these conventions is apparently not because of any policy disagreement, as is clear from active and fruitful Indian participation in the formulation of rules adopted by the conventions, but perhaps because of other circumstances, such as lack of an adequate and specialized machinery for implementation of the various international conventions by co-ordinating for the purpose the concerned Departments of the Government. Such a specialized body of legal and technical experts can facilitate adoption of internationally unified rules by national legislation. It is appropriate that sufficient attention is paid to this aspect of the matter by the concerned authorities. Perhaps the Law Commission of India, endowed as it ought to be with sufficient authority, status and independence, as is the position in England, can render valuable help in this regard. Delay in the adoption of international conventions which are intended to facilitate trade hinders the economic growth of the nation.

93. Admiralty jurisdiction, despite the peculiarities of its origin and growthrooted as it is in history and nurtured by the growing demands of international trade-is nevertheless a part of the totality of jurisdiction vested in the High Court as a superior Court of record, and it is not a distinct and separate jurisdiction as was once the position in England before the unification of courts. The 1890 and 1891 Acts specifically conferred admiralty jurisdiction on the Indian High Courts by reason of their being courts of unlimited 
jurisdiction. These Acts did not create any separate or distinct jurisdiction, but merely equated the Indian High Courts to the position of the English High Court (united and consolidated as that Court has been since 1875) for the exercise of admiralty powers within the jurisdiction of the former. The contrary view expressed in some of the decisions of the High Courts referred to earlier is clearly wrong.

94. Once a foreign ship is arrested in Indian waters by an order of the High Court, in exercise of the admiralty jurisdiction vested in it by statute, or inherent in it as a Court of record, in respect of any maritime claim against its owner, wherever the cause of action may have arisen, and whether or not the ship is subsequently released by the owner furnishing security, proceedings must continue against the owner as in any other suit ...

95. All foreign ships entering Indian waters are presumed to know that they fall within the jurisdiction of this country during their stay here. The vessel in question was lying in the Port of Vishakapatnam when she was arrested in respect of a cause of action relating to cargo. The sole contention of the defendants as regards jurisdiction was that no High Court in India was invested with admiralty jurisdiction to order the arrest of the vessel in respect of a cause of action relating to outward cargo because section 6 of the Admiralty Court Act, 1861 (read with the Colonial Courts of Admiralty Act, 1890) conferring admiralty jurisdiction on Indian High Courts confined it to "claims for damage to cargo imported". This contention, for the reasons we have stated, has no merits. The High Court, in our view, rightly assumed jurisdiction by the arrest of the vessel while it was lying in the port of Vishakapatnam.

96. The High Court of Andhra Pradesh undoubtedly possesses jurisdiction over claims relating to inward and outward cargo. In the circumstances, the preliminary objection to the jurisdiction of the Andhra Pradesh High Court was totally devoid of merits.

97. Accordingly, the appeal arising from SLP(C) No. 10542 of 1985 has to be dismissed...

R.M. SAHAI, J.: [concurring] 
International commercial arbitration; The proper law of the contract [or an arbitration agreement] and its determination; To be distinguished from the law governing arbitration proceedings; Applicability of [section 9 of] the [Indian] Foreign Awards (Recognition and Enforcement) Act, 1961 or the [Indian] Arbitration Act, 1940 to an award made at London by a tribunal constituted by the International Court of Arbitration of the International Chamber of Commerce.

Supreme Court, 7 May 1992

JT 1992 (3) S.C. 198*

Dr. T. KoChu ThOMmen and S.C. AgRawal, JJ.

National Thermal Power Corporation v. The Singer Company \& OTHERS

THOMMEN, J.:

2. The National Thermal Power Corporation (the "NTPC") appeals from the judgment of the Delhi High Court in FAO (OS) No.102/90 dismissing the NTPC's application filed under sections 14, 30 and 33 of the Arbitration Act, 1940 (No. X of 1940) to set aside an interim award made at London by a tribunal constituted by the International Court of Arbitration of the International Chamber of Commerce (the "ICC Court") in terms of the contract made at New Delhi between the NTPC and the respondent-the Singer Company (the "Singer") for the supply of equipment, erection and commissioning of certain works in India. The High Court held that the award was not governed by the Arbitration Act, 1940; the arbitration agreement on which the award was made was not governed by the law of India; the award fell within the ambit of the Foreign Awards (Recognition and Enforcement) Act, 1961 (Act 45 of 1961) (the "Foreign Awards Act"); London being the seat of arbitration, English Courts alone had jurisdiction to set aside the award; and, the Delhi High Court had no jurisdiction to entertain the application filed under the Arbitration Act, 1940.

3. The NTPC and the Singer entered into two formal agreements dated 17.8.1982 at New Delhi. The General Terms and Conditions of Contract dated 14.2.81 (the "General Terms") are expressly incorporated in the agreements and they state:

* Courtesy of Dr. T. Kochu Thommen, New Delhi. 
"the laws applicable to this Contract shall be the laws in force in India. The Courts of Delhi shall have exclusive jurisdiction in all matters arising under this contract." (7.2).

The General Terms deal with the special responsibilities of foreign contractors and Indian contractors. The Singer, being a foreign contractor, is governed by the provisions relating to the foreign contractors. The General Terms further provide for settlement of disputes by amicable settlement, failing which by arbitration.

4. Sub-clause 6 of clause 27 of the General Terms deals with arbitration in relation to an Indian contractor and sub-clause 7 of the said clause deals with arbitration in respect of a foreign contractor. The latter provision says:

"27.7. In the event of foreign Contractor, the arbitration shall be conducted by three arbitrators, one each to be nominated by the Owner and the Contractor and the third to be named by the President of the International Chamber of Commerce, Paris. Save as above all Rules of Conciliation and Arbitration of the International Chamber of Commerce shall apply to such arbitrations. The arbitration shall be conducted at such places as the arbitrators may determine."

In respect of an Indian Contractor, sub-clause 6.2 of clause 27 says that the arbitration shall be conducted at New Delhi in accordance with the provisions of the Arbitration Act, 1940.

... The General Terms further provide:

"the Contract shall in all respects be construed and governed according to Indian laws."(32.3).

The formal agreements which the parties executed on 17.8.82 contain a specific provision for settlement of disputes. Article 4.1 provides:

"4.1. Settlement of Disputes: It is specifically agreed by and between the parties that all the differences or disputes arising out of the contract or touching the subject matter of the contract, shall be decided by process of settlement and arbitration as specified in clause 26.0 and 27.0 excluding 27.6.1 and 27.6.2., of the General Conditions of the Contract."

5. ...

6. Accordingly, the dispute which arose between the parties was referred to an Arbitral Tribunal constituted in terms of the rules of arbitration of the ICC Court ("the ICC Rules"). In accordance with Article 12 of those Rules the ICC Court chose London to be the place of arbitration. 
7. The point for consideration is whether the High Court was right in rejecting the appellant's application filed under the provisions of the Arbitration Act, 1940 and in holding that the award which was made in London on an arbitration agreement was not governed by the law of India and that it was a foreign award within the meaning of the Foreign Awards Act and beyond the jurisdiction of the Indian Courts except for the purpose of recognition and enforcement under the latter Act.

8. The award was made in London as an interim award in an arbitration between the NTPC and a foreign contractor on a contract governed by the law of India and made in India for its performance solely in India. The fundamental question is whether the arbitration agreement contained in the contract is governed by the law of India so as to save it from the ambit of the Foreign Awards Act and attract the provisions of the Arbitration Act, 1940. Which is the law which governs the agreement on which the award has been made?

9. Mr. Shanti Bhushan, appearing for the NTPC, submits that admittedly the proper law of the contract is the law in force in India. The arbitration agreement is contained in a clause of that contract. In the absence of any stipulation to the contrary, the contract has to be seen as a whole and the parties must be deemed to have intended that the substantive law applicable to the arbitration agreement is exclusively the law which governs the main contract, although, in respect of procedural matters, the competent courts in England will also be, concurrently with the Indian courts, entitled to exercise jurisdiction over the conduct of arbitration. But occasions for interference by the courts in England would indeed be rare and probably unnecessary in view of the elaborate provisions contained in the ICC Rules by which the parties have agreed to abide. The substantive law governing arbitration, which concerns questions like capacity, validity, effect and interpretation of the contract etc., is Indian law and the competent courts in such matters are the Indian courts. Even in respect of procedural matters, the concurrent jurisdiction of the courts of the place of arbitration does not exclude the jurisdiction of the Indian courts.

10. Mr. S.K. Dholakia appearing for the Singer, on the other hand, submits that the arbitration agreement is a separate and distinct contract, and collateral to the main contract. Although the main contract is governed by the laws in force in India, as stated in the General Terms, there is no express statement as regards the law governing the arbitration agreement. In the circumstances, the 
law governing the arbitration agreement is not the same law which governs the contract, but it is the law which is in force in the country in which the arbitration is being conducted. Counsel accordingly submits that the Delhi High Court is right in saying that the saving clause in section 9 of the Foreign Awards Act has no application to the award in question made in London by an Arbitral Tribunal constituted in accordance with the ICC Rules. Counsel submits that the High Court has rightly held that the impugned award falls under the Foreign Awards Act and it is not liable to be challenged on the alleged grounds falling under sections 14, 30 and 33 of the Arbitration Act, 1940.

11. Counsel says that the award, having been made in London in terms of the ICC Rules to which the parties have submitted, is governed by the provisions of the New York Convention, as incorporated in the Foreign Awards Act, and its enforceability in India can be resisted only in the circumstances postulated under that Act, and the Delhi High Court has rightly rejected the petition invoking the jurisdiction of that Court in terms of the Arbitration Act, 1940.

12. Mr. Dholakia does not dispute that the substantive rights of the parties under the Contract are governed by the law of India. His contention, however, is that while the main contract is governed by Indian law, as expressly stated by the parties, arbitration being a collateral contract and procedural in nature, it is not necessarily bound by the proper law of the contract, but the law applicable to it must be determined with reference to other factors. The place of arbitration is an important factor. London having been chosen in accordance with the ICC Rules to be the seat of arbitration, English law is the proper law of arbitration, and all proceedings connected with it are governed by that law and exclusively within the jurisdiction of the English courts. He denies that the Indian courts have any jurisdiction in matters connected with the arbitration, except to the extent permitted by the Foreign Awards Act for recognition and enforcement of the award.

13. Dicey \& Morris in The Conflict of Laws, 11th edn., Vol. II ("Dicey") refer to the "proper law of a contract" thus:

The expression "proper law of a contract" refers to the legal system by which the parties to the contract intended their contract to be governed. If their intention is expressly stated or if it can be clearly inferred from the contract itself or its surrounding circumstances, such intention determines the proper law of the contract. In the words of Lord HERCHELL L.C.... 
Where, however, the intention of the parties is not expressly stated and no inference about it can be drawn, their intention as such has no relevance. In that event, the courts endeavour to impute an intention by identifying the legal system with which the transaction has its closest and most real connection.

14. The expressed intention of the parties is generally decisive in determining the proper law of the contract. The only limitation on this rule is that the intention of the parties must be expressed bona fide and it should not be opposed to public policy. In the words of Lord WRIGHT: ...

15. In the absence of an express statement about the governing law, the inferred intention of the parties determines that law. The true intention of the parties, in the absence of an express selection, has to be discovered by applying "sound ideas of business, convenience and sense to the language of the contract itself'. Jacobs Marcus \& Co. v. The Credit Lyonnais (1884) 12 Q.B.D. 589, 601 (C.A.). In such a case, selection of courts of a particular country as having jurisdiction in matters arising under the contract is usually, but not invariably, by an indication of the intention of the parties that the system of law followed ... those courts is the proper law by which they intend their contract to be governed. However, the mere selection of a particular place for submission to the jurisdiction of the courts or for the conduct of arbitration will not, in the absence of any other relevant connecting factor with that place, be sufficient to draw an inference as to the intention of the parties to be governed by the system of law prevalent in that place. This is specially so in the case of arbitration, for the selection of the place of arbitration may have little significance where it is chosen, as is often the case, without regard to any relevant or significant link with the place. This is particularly true when the place of arbitration is not chosen by the parties themselves, but by the arbitrators or by an outside body, and that too for reasons unconnected with the contract. Choice of place for submission to jurisdiction of courts or for arbitration may thus prove to have little relevance for drawing an inference as to the governing law of the contract, unless supported in that respect by the rest of the contract and the surrounding circumstances. Any such clause must necessarily give way to stronger indications in regard to the intention of the parties. See The Fehmarn, (1958) 1 All E.R. 333.

16. Where the parties have not expressly or impliedly selected the proper law, the courts impute an intention by applying the objective test to determine what the parties would have as just and reasonable persons intended as regards the applicable law had they applied their minds to the question. The judge has to determine the proper law for the parties in such circumstances by putting himself in the place of a "reasonable man". He has to determine the intention 
of the parties by asking himself "how a just and reasonable person would have regarded the problem", The Assunzione (1954) P. 150, 176 (C.A.); Mount Albert Borough Council v. Australasian Temperance and General Mutual Life Assurance Society Ltd. (1938) A.C. 224, 240 (P.C.).

17. For this purpose the place where the contract was made, the form and object of the contract, the place of performance, the place of residence or business of the parties, reference to the courts having jurisdiction and such other links are examined by the courts to determine the system of law with which the transaction has its closest and most real connection.

18. The position in these respects is summarized by the Privy Council in Mount Albert Borough Council v. Australasian Temperance and General Mutual Life Assurance Society Limited, (1938) A.C. 224 at 240: ...

It must, however, be clarified that the expression "proper law" refers to the substantive principles of the domestic law of the chosen system and not to its conflict of laws rules. The law of contract is not affected by the doctrine of renvoi. See Dicey, Vol. II, p. 1164.

20. In a case such as the present, there is no need to draw any inference about the intention of the parties or to impute any intention to them, for they have clearly and categorically stipulated that their contract, made in India to be performed in India, is to be governed by the "laws in force in India" and the courts in Delhi are to "have exclusive jurisdiction in all matters arising under this contract" (cl.7). The cardinal test suggested by Dicey in rule 180 is thus fully satisfied.

\section{As regards the governing law of arbitration, Dicey says:}

"Rule 58.-(1) The validity, effect and interpretation of an arbitration agreement are governed by its proper law.

(2) The law governing arbitration proceedings is the law chosen by the parties, or, in the absence of agreement, the law of the country in which the arbitration is held." (Vol. I, Pages 534-535).

22. The principle in rule 58, as formulated by Dicey, has two aspects-(a) the law governing the arbitration agreement, namely, its proper law; and (b) the law governing the conduct of the arbitration, namely, its procedural law.

23. The proper law of the arbitration agreement is normally the same as the proper law of the contract. It is only in exceptional cases that it is not so even where the proper law of the contract is expressly chosen by the parties. Where, 
however, there is no express choice of the law governing the contract as a whole, or the arbitration agreement as such, a presumption may arise that the law of the country where the arbitration is agreed to be held is the proper law of the arbitration agreement. But that is only a rebutable presumption. See Dicey, Vol. I, p. 539; see the observation in Whitworth Street Estates (Manchester) Ltd. v. James Miller \& Partners Ltd., 1970 AC 583, 607, 612 and 616).

24. The validity, effect and interpretation of the arbitration agreement are governed by its proper law. Such law will decide whether the arbitration clause is wide enough to cover the dispute between the parties. Such law will also ordinarily decide whether the arbitration clause binds the parties even when one of them alleges that the contract is void, or voidable or illegal or that such contract has been discharged by breach or frustration. See Heymann \& Anr. v. Darwins, Ltd., 1942 (1) All E.R. 337. The proper law of arbitration will also decide whether the arbitration clause would equally apply to a different contract between the same parties or between one of those parties and a third party.

25. The parties have the freedom to choose the law governing an international commercial arbitration agreement. They may choose the substantive law governing the arbitration agreement as well as the procedural law governing the conduct of the arbitration. Such choice is exercised either expressly or by implication. Where there is no express choice of the law governing the contract as a whole, or the arbitration agreement in particular, there is, in the absence of any contrary indication, a presumption that the parties have intended that the proper law of the contract as well as the law governing the arbitration agreement are the same as the law of the country in which the arbitration is agreed to be held. On the other hand, where the proper law of the contract is expressly chosen by the parties, as in the present case, such law must, in the absence of an unmistakable intention to the contrary, govern the arbitration agreement which, though collateral or ancillary to the main contract, is nevertheless a part of such contract.

26. Whereas, as stated above, the proper law of arbitration (i.e., the substantive law governing arbitration) determines the validity, effect and interpretation of the arbitration agreement, the arbitration proceedings are conducted, in the absence of any agreement to the contrary, in accordance with the law of the country in which the arbitration is held. On the other hand, if the parties have specifically chosen the law governing the conduct and procedure of arbitration, the arbitration proceedings will be conducted in accordance with that law so long as it is not contrary to the public policy or the mandatory requirements of the law of the country in which the arbitration is held. If no such choice has been made by the parties, expressly or by necessary implication, the procedural aspect of the conduct of arbitration (as 
distinguished from the substantive agreement to arbitrate) will be determined by the law of the place or seat of arbitration. Where, however, the parties have, as in the instant case, stipulated that the arbitration between them will be conducted in accordance with the ICC Rules, those rules, being in many respects self-contained or self-regulating and constituting a contractual code of procedure, will govern the conduct of the arbitration, except insofar as they conflict with the mandatory requirements of the proper law of arbitration, or of the procedural law of the seat of arbitration. See the observation of Kerr, L.J. in Bank Mellat v. Helliniki Techniki SA, (1983) 3 All E.R. 428; See also Craig, Park and Paulsson, International Chamber of Commerce Arbitration, 2nd ed. (1990). To such an extent the appropriate courts of the seat of arbitration, which in the present case are the competent English courts, will have jurisdiction in respect of procedural matters concerning the conduct of arbitration. But the overriding principle is that the courts of the country whose substantive laws govern the arbitration agreement are the competent courts in respect of all matters arising under the arbitration agreement, and the jurisdiction exercised by the courts of the seat of arbitration is merely concurrent and not exclusive and strictly limited to matters of procedure. All other matters in respect of the arbitration agreement fall within the exclusive competence of the courts of the country whose laws govern the arbitration agreement. See Mustil \& Boyd, Commercial Arbitration, 2nd ed.; Allen Redfern and Martin Hunter, Law \& Practice of International Commercial Arbitration, 1986; Russel on Arbitration, Twentieth ed., 1982; Cheshire \& North's Private International Law, eleventh ed. (1987).

27. The proper law of the contract in the present case being expressly stipulated to be the laws in force in India and the exclusive jurisdiction of the courts in Delhi in all matters arising under the contract having been specifically accepted, and the parties not having chosen expressly or by implication a law different from the Indian law in regard to the agreement contained in the arbitration clause, the proper law governing the arbitration agreement is indeed the law in force in India, and the competent courts of this country must necessarily have jurisdiction over all matters concerning arbitration. Neither the rules of procedure for the conduct of arbitration contractually chosen by the parties (the ICC Rules) nor the mandatory requirements of the procedure followed in the courts of the country in which the arbitration is held can in any manner supersede the overriding jurisdiction and control of the Indian law and the Indian courts.

28. This means, questions such as the jurisdiction of the arbitrator to decide a particular issue or the continuance of an arbitration or the frustration of the arbitration agreement, its validity, effect and interpretation are determined exclusively by the proper law of the arbitration agreement, which, in the present case, is Indian Law. The procedural powers and duties of the 
arbitrators, as for example, whether they must hear oral evidence, whether the evidence of one party should be recorded necessarily in the presence of the other party, whether there is a right of cross-examination of witnesses, the special requirements of notice, the remedies available to a party in respect of security for costs or for discovery etc. are matters regulated in accordance with the rules chosen by the parties to the extent that those rules are applicable and sufficient and are not repugnant to the requirements of the procedural law and practice of the seat of arbitration. The concept of party autonomy in international contracts is respected by all systems of law so far as it is not incompatible with the proper law of the contract or the mandatory procedural rules of the place where the arbitration is agreed to be conducted or any overriding public policy.

29. The arbitration agreement contained in the arbitration clause in a contract is often referred to as a collateral or ancillary contract in relation to the main contract of which it forms a part. The repudiation or breach of the main contract may not put an end to the arbitration clause which might still survive for measuring the claims arising out of the breach and for determining the mode of their settlement. See Heyman \& Anr. v. Darwins, Ltd., 1942 (1) All E.R. 337; Bremer Vulkan Schiffbau Und Maschinenfabrik v. South India Shipping Corpn., 1981(1) All E.R. 289. See also Mustil \& Boyd, Commercial Arbitration, 2nd ed. (1989).

30. The arbitration agreement may provide that all disputes which may arise between the parties will be referred to arbitration or it may provide that a particular dispute between the parties will be submitted to the jurisdiction of a particular arbitrator. The arbitration clause may identify the arbitrator or arbitrators and the place of arbitration or it may leave such matters to be determined by recourse to the machinery of an institutional arbitration, such as the ICC, or the London Court of International Arbitration or the American Arbitration Association or similar institutions.

33. An international commercial arbitration necessarily involves a foreign element giving rise to questions as to the choice of law and the jurisdiction of courts. Unlike in the case of persons belonging to the same legal system, contractual relationships between persons belonging to different legal systems may give rise to various private international law questions such as the identity of the applicable law and the competent forum. An award rendered in the territory of a foreign State may be regarded as a domestic award in India where it is sought to be enforced by reason of Indian law being the proper law governing the arbitration agreement in terms of which the award was made. The Foreign Awards Act, incorporating the New York Convention, leaves no 
room for doubt on the point.

35. The difference between an ad hoc arbitration and an institutional arbitration is not a difference between one system of law and another; for whichever is the proper law which governs either proceeding, it is merely a difference in the method of appointment and conduct of arbitration. Either method is applicable to an international arbitration, but neither is determinative of the character of the resultant award, namely, whether or not it is a foreign award as defined under the Foreign Awards Act, 1961.

36. Where the ICC Rules apply, there is generally little need to invoke the procedural machinery of any legal system in the actual conduct of arbitration.

37. A 'foreign award', as defined under the Foreign Awards Act, 1961 means an award made on or after 11.10 .1960 on differences arising between persons out of legal relationships, whether contractual or not, which are considered to be commercial under the law in force in India. To qualify as a foreign award under the Act, the award should have been made in pursuance of an agreement in writing for arbitration to be governed by the New York Convention on the Recognition and Enforcement of Foreign Arbitral Awards, 1958, and not to be governed by the law of India. Furthermore such an award should have been made outside India in the territory of a foreign State notified by the Government of India as having made reciprocal provisions for enforcement of the Convention. These are the conditions which must be satisfied to qualify an award as a "foreign award" (S.2 read with S.9).

38. An award is "foreign" not merely because it is made in the territory of a foreign State, but because it is made in such a territory on an arbitration agreement not governed by the law of India. An award made on an arbitration agreement governed by the law of India, though rendered outside India, is attracted by the saving clause in S.9 of the Foreign Awards Act and is, therefore, not treated in India as a "foreign award".

39. A "foreign award" is (subject to section 7) recognized and enforceable in India "as if it were an award made on a matter referred to arbitration in India" (S.4). Such an award will be ordered to be filed by a competent Court in India which will pronounce judgment according to the award (S.6).

40. Section 7 of the Foreign Awards Act, in consonance with Art. V of the New York Convention which is scheduled to the Act, specifies the conditions under which recognition and enforcement of a foreign award will be refused at 
the request of a party against whom it is invoked.

41. A foreign award will not be enforced in India if it is proved by the party against whom it is sought to be enforced that the parties to the agreement were, under the law applicable to them, under some incapacity, or, the agreement was not valid under the law to which the parties have subjected it, or, in the absence of any indication thereon, under the law of the place of arbitration; or there was no due compliance with the rules of fair hearing; or the award exceeded the scope of the submission to arbitration; or the composition of the arbitral authority or its procedure was not in accordance with the agreement of the parties, or, failing such agreement, was not in accordance with the law of the place of arbitration; or "the award has not yet become binding on the parties, or has been set aside or suspended by a competent authority of the country in which, or under the law of which, that award was made". The award will not be enforced by a Court in India if it is satisfied that the subject matter of the award is not capable of settlement by arbitration under Indian law or the enforcement of the award is contrary to the public policy.

42. The Foreign Awards Act contains a specific provision to exclude its operation to what may be regarded as a "domestic award" in the sense of the award having been made on an arbitration agreement governed by the law of India, although the dispute was with a foreigner and the arbitration was held and the award was made in a foreign State.

\section{Section 9 of this Act says:-}

"Nothing in this Act shall -

(a)

(b) apply to any award made on an arbitration agreement governed by the law of India."

Such an award necessarily falls under the Arbitration Act, 1940, and is amenable to the jurisdiction of the Indian Courts and controlled by the Indian system of law just as in the case of any other domestic award, except that the proceedings held abroad and leading to the award were in certain respects amenable to be controlled by the public policy and the mandatory requirements of the law of the place of arbitration and the competent courts of that place.

44. It is important to recall that in the instant case the parties have expressly stated that the laws applicable to the contract would be the laws in force in India and that the courts of Delhi would have exclusive jurisdiction "in all matters arising under this contract". They have further stated that the "Contract shall in all respects be construed and governed according to Indian 
laws". These words are wide enough to engulf every question arising under the contract including the disputes between the parties and the mode of settlement. It was in Delhi that the agreement was executed. The form of the agreement is closely related to the system of law in India. Various Indian enactments are specifically mentioned in the agreement as applicable to it in many respects. The contract is to be performed in India with the aid of Indian workmen whose conditions of service are regulated by Indian laws. One of the parties to the contract is a public sector undertaking. The contract has in every respect the closest and most real connection with the Indian system of law and it is by that law that the parties have expressly evinced their intention to be bound in all respects. The arbitration agreement is contained in one of the clauses of the contract, and not in a separate agreement. In the absence of any indication to the contrary, the governing law of the contract (i.e., in the words of Dicey, the proper law of the contract) being Indian law, it is that system of law which must necessarily govern matters concerning arbitration, although in certain respects the law of the place of arbitration may have its relevance in regard to procedural matters.

45. It is true that an arbitration agreement may be regarded as a collateral or ancillary contract in the sense that it survives to determine the claims of the parties and the mode of settlement of their disputes even after the breach or repudiation of the main contract. But is it not an independent contract, and it has no meaningful existence except in relation to the rights and liabilities of the parties under the main contract. It is a procedural machinery which is activated when disputes arise between parties regarding their rights and liabilities. The law governing such rights and liabilities is the proper law of the contract, and unless otherwise provided, such law governs the whole contract including the arbitration agreement, and particularly so when the latter is contained not in a separate agreement, but, as in the present case, in one of the clauses of the main contract.

46. Significantly, London was chosen as the place of arbitration by reason of Article 12 of the ICC Rules which reads:

"The place of arbitration shall be fixed by the International Court of Arbitration, unless agreed upon by the parties."

The parties had never expressed their intention to choose London as the arbitral forum, but, in the absence of any agreement on the question, London was chosen by the ICC Court as the place of arbitration. London has no significant connection with the contract or the parties except that it is a neutral place and the Chairman of the Arbitral Tribunal is a resident there, the other two members being nationals of the United States and India respectively.

47. The decisions relied on by counsel for the Singer do not support his 
contention that the mere fact of London being the place of arbitration excluded the operation of the Arbitration Act, 1940 and the jurisdiction of the courts in India....

The observations contained in [James Miller \& Partners Ltd v. Whitworth Street Estates (Manchester) Ltd. (1970) A.C. 583] do not support the contention urged on behalf of the Singer that merely because London was designated to be the place of arbitration, the law which governed arbitration was different from the law expressly chosen by the parties as the proper law of the contract.

48. It is true that the procedural law of the place of arbitration and the courts of that place cannot be altogether excluded, particularly in respect of matters affecting public policy and other mandatory requirements of the legal system of that place. But in a proceeding such as the present which is intended to be controlled by a set of contractual rules which are self-sufficient and designed to cover every step of the proceeding, the need to have recourse to the municipal system of law and the courts of the place of arbitration is reduced to the minimum and the courts of that place are unlikely to interfere with the arbitral proceedings except in cases which shock the judicial conscience. See the observations of Kerr LJ in Bank Mellat v. Helliniki Techniki SA, (1983) 3 All E.R. 428.

49. Courts would give effect to the choice of a procedural law other than the proper law of the contract only where the parties had agreed that matters of procedure should be governed by a different system of law. If the parties had agreed that the proper law of the contract should be the law in force in India, but had also provided for arbitration in a foreign country, the laws of India would undoubtedly govern the validity, interpretation and effect of all clauses including the arbitration clause in the contract as well as the scope of the arbitrators' jurisdiction. It is Indian law which governs the contract, including the arbitration clause, although in certain respects regarding the conduct of the arbitration proceedings the foreign procedural law and the competent courts of that country may have a certain measure of control. See the principle stated by Lord Denning, M.R. in International Tank and Pipe SAK v. Kuwait Aviation Fueling Co. KSC, (1975) 1 All E.R. 242.

50. The arbitration clause must be considered together with the rest of the contract and the relevant surrounding circumstances. In the present case, as seen above, the choice of the place of arbitration was, as far as the parties are concerned, merely accidental in so far as they had not expressed any intention in regard to it and the choice was made by the ICC Court for reasons totally unconnected with either party to the contract. On the other hand, apart from the expressly stated intention of the parties, the contract itself, including the 
arbitration agreement contained in one of its clauses, is redolent of India and matters Indian. The disputes between the parties under the contract have no connection with anything English, and they have the closest connection with Indian laws, rules and regulations. In the circumstances, the mere fact that the venue chosen by the ICC Court for the conduct of arbitration is London does not support the case of the Singer on the point. Any attempt to exclude the jurisdiction of the competent courts and the laws in force in India is totally inconsistent with the agreement between the parties.

51. In sum, it may be stated that the law expressly chosen by the parties in respect of all matters arising under their contract, which must necessarily include the agreement contained in the arbitration clause, being Indian law and the exclusive jurisdiction of the courts in Delhi having been expressly recognized by the parties to the contract in all matters arising under it, and the contract being most intimately associated with India, the proper law of arbitration and the competent courts are both exclusively Indian, while matters of procedure connected with the conduct of arbitration are left to be regulated by the contractually chosen rules of the ICC to the extent that such rules are not in conflict with the public policy and the mandatory requirements of the proper law and of the law of the place of arbitration. The Foreign Awards Act, 1961 has no application to the award in question which has been made on an arbitration agreement governed by the law of India.

52. The Tribunal has rightly held that the "substantive law of the contract is Indian law". The Tribunal has further held "the laws of England govern procedural matters in the arbitration".

53. All substantive rights arising under the agreement including that which is contained in the arbitration clause are, in our view, governed by the laws of India. In respect of the actual conduct of arbitration, the procedural law of England may be applicable to the extent that the ICC Rules are insufficient or repugnant to the public policy or other mandatory provisions of the laws in force in England. Nevertheless, the jurisdiction exercisable by the English courts and the applicability of the laws of that country in procedural matters must be viewed as concurrent and consistent with the jurisdiction of the competent Indian courts and the operation of Indian laws in all matters concerning arbitration in so far as the main contract as well as that which is contained in the arbitration clause are governed by the laws of India.

54. The Delhi High Court was wrong in treating the award in question as a foreign award. The Foreign Awards Act has no application to the award by reason of the specific exclusion contained in section 9 of that Act. The award is governed by the laws in force in India, including the Arbitration Act, 1940. Accordingly, we set aside the impugned judgment of the Delhi High Court and 
direct that Court to consider the appellant's application on the merits in regard to which we express no views whatsoever. The appeal is allowed in the above terms. We do not, however, make any order as to costs.

\section{PAKISTAN}

\section{JUDICIAL DECISIONS}

Rules of international law are incorporated into national law and considered to be part of the national law unless they are in conflict with an Act of Parliament; National courts being organs of the national state and not organs of international law, must perforce apply national law if international law conflicts with it; obligation to interpret the municipal statute as to avoid confrontation with the comity of nations or the well-established principles of international law; Restrictions on free transit of goods through Pakistan into Afghanistan in light of the Pakistan-Afghanistan Transit Trade Agreement of 2 March 1965.

High Court, Karachi, 9 September 1992

PLD 1993 Karachi 93*

SYed HAIDER Ali PIRZADA and Shaukat HussaIN Zubedi, JJ.

Messrs NaJib Zarab LIMITED-Petitioner v. Government of PAKISTAN THROUGH THE SECRETARY, MINISTRY OF FINANCE, ISLAMABAD AND 4 OTHERS-Respondents

\section{Facts}

The petitioners in the course of their business placed orders for import of tyres of Indian origin. About 18 consignments reached Karachi port on various dates between 1 January and 27 March 1990 . The consignments were imported for use in Afghanistan and were notified as goods in transit. According to the petitioners the Customs Authorities at Karachi refused clearance of the said consignments on the basis of a letter, dated 19th December 1989 allegedly received at the Customs House, Karachi on 1-1-1990 whereby the transit

* Courtesy of Mr. Jamshed A. Hamid, Islamabad. 
facility in respect of tyres for which letters of credit were opened on or before 15-12-1988 but had subsequently been amended, was discontinued. The letter dated 19-12-1989 was apparently issued in order to give effect to an earlier letter dated 14-1-1989 of the Central Board of Revenue purportedly issued in order to stop smuggling back to Pakistan of tyres and tubes going to Afghanistan in transit. The petitioners prayed to quash the letter/orders dated 14-1-1989 and 19-12-1989.

On behalf of the respondents it was contended that in respect of the balance quantity of tyres ready for shipment abroad transit facility could not be allowed in view of public notice issued by the Customs House, Karachi, dated 27(23?)-7-1990 in pursuance of a letter of the Central Board of Revenue of 187-1990. The Government after considering the misuse of Afghan transit goods smuggled from Afghanistan into Pakistan, imposed the said condition of withdrawing transit facility of tyres.

The Court by judgment of 24-3-1992 allowed the petition and quashed the impugned letters/orders of 14-1-1989 and 19-12-1989. The Government of Pakistan and 3 others being aggrieved against the judgment, filed petition for Leave to Appeal, later converted to regular appeal, before the Supreme Court.

The Supreme Court held that the High Court had neither examined the merits of the case in the light of section 129 of the Customs Act nor considered the effect of the Pakistan-Afghanistan Transit Trade Agreement of 2-3-1965. The order of the High Court of 24-3-1992 was set aside and the case was remanded with the direction that the petition may be re-heard and disposed of in terms of the above observations.

\section{SYed HAIDER Ali PIRZADA, J.:}

We shall first examine if there is any mandate of international law or if the rules of international law afford us any guidance and if such mandate or guidance is preceptive under Pakistan Law. Two questions arise for our consideration. Firstly, whether international law is, of its own force, drawn into the law of the land without the aid of a municipal law and, secondly, whether so drawn, it overrides municipal law in case of conflict. It has been said in England that there are two schools of thought, one school of thought propounding the doctrine of incorporation and the other, the doctrine of transformation (per Lord Denning M.R. in Trendtex Trading Corpn. v. Central Bank of Nigeria ((1977) 1 AER 881). According to the one, rules of international law are incorporated into the law of the land automatically and considered to be part of the law of the land unless in conflict with an Act of Parliament. According to the other, rules of international law are not part of the law of the land unless already so by an Act of Parliament, judicial decision or long established custom. According to the one, whenever the rules of International law changed, they would result in change of the law of the land 
along with them, without the aid of an Act of Parliament. According to the other, no such change would occur unless those principles are accepted and adopted by the domestic law.

We are of the view that nations must march with the international community and the municipal law must respect rules of international law, even as nations respect international opinion. The comity of nations requires that rules of international law may be accommodated in the municipal law even without express legislative sanction provided they do not run into conflict with Acts of Parliament. But when they do run into such conflict, the sovereignty and the integrity of the Republic and the supremacy of the constituted Legislatures in making laws, may not be subjected to external rules except to the extent legitimately accepted by the constituted Legislatures themselves. The doctrine of incorporation also recognizes the position that the rules of international law are incorporated into national law and considered to be part of the national law, unless they are in conflict with an Act of Parliament, comity of nations and municipal law must prevail in case of conflict. National Courts cannot say "yes" if Parliament has said "no" to a principle of international law. National Courts will endorse international law but not if it conflicts with national Law. National Courts being organs of the National State and not organs of international law, must perforce apply national law if international law conflicts with it. But the Courts are under an obligation within the legitimate limits, so to interpret the municipal statute as to avoid confrontation with the comity of nations or the well-established principles of international law. But if conflict is inevitable, the latter must yield.

The proposition has been well established....

In Halsbury's Laws of England (4th Edition), Volume 44, para.908 at page 559 , it is stated that "there is a presumption that Parliament does not assert or assume jurisdiction which goes beyond the limits established by the common consent of nations, and, provided their language admits, statutes are to be interpreted so as not to be inconsistent with the comity of nations or with the established principles of international law". But this principle applies only where there is an ambiguity and must give way before a clearly expressed intention. It is further stated that "if statutory enactments are clear in meaning, they must be construed according to their meaning even though they are contrary to the comity of nations or international law".

It appears that "the leading authorities on International Law have expressed 
divergent views on the question of the transit rights of land-locked countries. While one group of writers such as Sibert, Scelle and others have held the view that these countries have an inherent right of transit across neighbouring countries, other equally eminent authorities, such as McNair and Hyde have held the view that these rights are not principles recognized by International Law but arrangements made by Sovereign States".

The result of the lack of unanimity has been that the land-locked countries have to rely on bilateral, regional or multilateral agreements for the recognition of their rights. The very existence of innumerable bilateral treaties, while on the one hand it raises a presumption of the existence of a customary right of transit, on the other, it indicates the dependence of the right on agreement. The discontenting situation led to attempts by nations to codify the rules relating to transit trade. The earliest attempt was the Convention on the Freedom of Transit known generally as the Barcelona Convention. The second attempt was the Convention on the High Seas, 1958. The third was the 1965 Convention on Transit Trade of Land-locked States. The most recent is The United Nations Convention on the Law of [the] Sea signed at Montiago Bay on [sic] 10th December, 1982.

The 1965 Convention on Transit Trade of Land-locked States is the Convention on the subject and as both Pakistan and Afghanistan have signed the convention, it may be useful to refer to it in some detail. ...

... Article 2 prescribes that freedom of transit shall be granted under the terms of this Convention for traffic in transit and means of transport. Traffic in transit is to be facilitated on routes in use mutually acceptable for transit to the contracting States concerned. No discrimination is to be exercised based on the place of origin, departure, entry, exit or destination or any circumstances relating to the ownership of the goods or the ownership, place of registration or flag of vessels, land, vehicles or other means of transport used. Article 3 provides for exemption of Traffic in transit from Customs Duties or import or export taxes or other charges except charges levied for specific services rendered in connection with such traffic. Article 4 refers to means of transport and tariff. Article 5 refers to methods and documentation in regard to customs transport etc. facilities. Article 8 refers to free zones or other custom facilities. Article 9 refers to provision of greater facilities. Article 10 refers to relation to most-favoured nation clause. Article 6 refers to storage of goods in transit. Article 7 refers to delays or difficulties in traffic in transit.

We have now to take a look at the Afghan Transit Trade Agreement, 1965. The Agreement was executed between the Government of [the] Islamic Republic of Pakistan and the Government of the Kingdom of Afghanistan for regulation of traffic in transit on the 2nd March, 1965. ... Article I stipulates 
that the contracting parties undertake in accordance with the provisions of this agreement to grant and guarantee to each other the freedom of transit to and from their territories. It further provides that no distinction shall be made which is based on the flag of vessels, the place of origin, departure, entry, exit or destination or any other circumstances relating to the ownership of goods, of vessels or other means of transport. Article II stipulates that goods including baggage, and vessels and other means of transport shall be deemed to be in transit across the territory of a contracting party, when the passage across such territory with or without transhipment, warehousing, breaking bulk or change in the mode of transport, is only a portion of a complete journey beginning and terminating beyond the frontier of the Contracting Party across whose territory the traffic passes-traffic of this nature is termed in this Agreement "Traffic in Transit". According to Article III, the transit routes shall be (1) Peshawar-Torkhum and vice versa and (2) Chaman-Spin Baldak and vice versa. The additional routes may be agreed between the Contracting Parties from time to time. Goods moving via these routes shall be entered at the proper Customs posts prescribed by each party. Adequate transit and other facilities shall be provided by the Contracting Party concerned at these posts. Article IV provides that no customs duties, taxes, dues or charges of any kind whether national, provincial or municipal shall regardless of their name and purpose, shall be levied on traffic in transit except charges for transportation or those commensurate with the administrative expenses entailed by traffic in transit or with the cost of services rendered. It further provides that with a view to achieving simplification of existing customs practices and procedures, the Contracting Parties agree to adopt at points of entry and exit the procedures laid down in the Annexure to the Agreement. Article V provides that without prejudice to the generality of the provisions contained in Article III, the Government of [the] Islamic Republic of Pakistan shall earmark sheds and open spaces in the Karachi Port Area to be known as Afghan Transit Area, for the goods in transit to and from Afghanistan. For hazardous and awkward goods separate arrangements for storage will be made as indicated in the Annexure. Article VI provides that the two Contracting Parties, recognizing the importance of the Kabul-Torkham Peshawar transit route, have decided to examine all matters pertinent to the development of this route, including consideration of the extension of the railway from Landi Khana to Torkham, Article VII provides that the Government of the Islamic Republic of Pakistan undertake to meet in full the requirement of wagons for transit traffic on both Karachi-Spin Baldak and Peshawar-Karachi routes. Article VIII enjoins on each Contracting Party to appoint liaison officers to look into the working of this Agreement and to refer, for expeditious solution, to the appropriate authorities of their own country, and to the liaison officer of the other country, any question arising from the operation of this Agreement. The liaison officers will meet as often as necessary and in any case not less than once in six months and the Contracting Parties shall provide them with the necessary facilities. 
Article IX provides that the Contracting Parties agree that railway freight, port and other dues shall be subject to the most sympathetic consideration and shall be no less favourable than those imposed by either party on goods owned by its own nationals. Article $X$ specifically provides that nothing in this Agreement shall be construed to prevent the adoption and enforcement by either party of measures necessary to protect public morals, human, animal or plant life or health and for the security of its own territory. Article XI provides that the Contracting Parties shall meet and consult each other once a year to review the working of this Agreement. Article XII provides that the Contracting Parties agree to resolve any difference relating to the interpretation of this Agreement by negotiation and in the event of failure to reach a settlement, to refer the matter to an arbitrator acceptable to both parties, whose decision shall be binding. Article XIII provides that nothing in this Agreement or its Annexures will affect in any way the political stand of the two countries or the political difference existing between them, and the Contracting Parties fully reserve their rights with regard to these subjects. Article XIV provides that this Agreement shall be ratified and the Instruments of Ratification shall be exchanged at Rawalpindi. The Agreement shall come into force from the date of the exchange of the Instruments of Ratification and shall remain in force for five years from the date it comes into force. Unless notice of termination is given in writing by either Contracting Party to the other six months before the expiration of the five years period, the Agreement shall be automatically renewed for a further period of five years. It can thereafter be terminated by either Party at any time provided six months notice of termination is given by either party. Article XV provides that the present Agreement is drawn in duplicate in [the] English and Dari Languages, both texts being equally valid.

The protocol annexed to [the] Transit Agreement contains a detailed procedure for the transit of goods across the territory of Pakistan en route from the Port of Karachi to the Afghanistan destination. The protocol contains detailed provisions to ensure the goods reaching Afghanistan and to prevent the contingency of the goods escaping into the Pakistan market while on the way to Afghanistan. The protocol contains detailed provisions for granting transporters multiple entry visas, freight, driving licences and certificates of fitness in respect of transport vehicles covered by this protocol. Article 8 of the protocol provides that the two Governments shall consult each other with a view to adopting necessary measures to facilitate the flow of traffic between the two countries and shall seek all possible means within their power to remove any factors which may damage the normal accomplishment of the operation foreseen in the protocol.

... In the payment of Customs Duties, taxes, dues or charges of any kind, the 
Transit Agreement grants exemption from such payment. The Transit Agreement contains reservations. There is a reservation enabling the imposition of such restrictions as are necessary for the purpose of protecting public morals, human, animal and plant life or health and for the security of its own country.

The question for consideration is that the imposition of restriction on tyres and trucks would be for the purpose of protecting public morals and/or for the security of its own territory. The case of the respondents Nos. 1 to 3, as set out in the parawise comments, is that in view of the mounting complaints of smuggling back, the respondents Nos. 2 and 3 have banned the import of tyres and tubes as envisaged under section 129 of the Customs Act, 1969 read with Pak-Afghan Transit Trade Agreement. ... The case of the respondents is that the sole intention was that import of subject goods was considered detrimental to the economic security in terms of Article X of the Pak-Afghan Transit Trade Agreement. It is further stated in the comments that the Government allowing the facility of transit have every right to protect their own interest and sovereignty, if their legitimate interests are threatened.

The grievance of respondents seems to have been that the goods are being imported under the guise of import to Afghanistan and these were finding their way back across the Afghanistan-Pakistan border into [the] Pakistan market to the gross prejudice to the Government. If the goods which were trans-shipped through Pakistan or were in transit or are in transit re-entered into Pakistan by violation of law or treaty, the Customs Law would be broken.

... [I]n our opinion, it would be wrong to say that the moment the goods crossed the custom[s] barrier or entered into the Pakistan territorial waters as defined in the Customs Act, they should be construed to have been imported into Pakistan under the Customs Act and the other provisions relating to importation would be applicable for importation of these goods. Looking at it from another point of view, if we accept the contention of the respondents advanced in this case, then that would mean all goods which are prohibited in Pakistan but which are not prohibited in Afghanistan could not have transit as such through Pakistan. That, in our opinion, would not be a reasonable construction to make specially keeping in view the background of the treaty and the protocol which we have mentioned hereinbefore. If the grievance of the respondents was, as it seems to have been, that the tyres and tubes after entering into Afghanistan illegally re-entered into Pakistan and are mixed up with the mass of other tyres and tubes, then other remedies might be open to the respondents. ... We are, however, of the view that the provisions of [the] 
Customs Act and Import and Export Control Order dealt with different kinds of situation, i.e. after being imported into Pakistan and imported in Afghanistan. The provisions of [the] Customs Act do not deal with goods in transit which were not really imported into Pakistan.

In the result, the petition succeeds and is allowed. The letters/orders dated 14-1-1989 and 19-12-1989 are quashed. The respondents Nos.3 to 5 are directed to perform their functions in respect of Afghan transit goods in terms of the treaty and protocol and in disregard to letters dated 14-1-1989 and 1912-1989. We direct the respondents to clear the stock involved in the petition for immediate transit to Afghanistan. We also direct the respondent No.4 to issue [a] delay detention certificate. In the circumstances of the case, the parties are directed to bear their own costs.

Petition accepted.

\section{THE PHILIPPINES}

(Prepared and contributed by R.P.M. Lotilla, director, Institute of International Legal Studies, University of the Philippines)

\section{JUDICIAL DECISIONS}

\section{Immunity of international organizations from jurisdiction}

Southeast Asian Fisheries Development Center-Aquaculture DEPARTMENT v. NATIONAL LABOUR RELATIONS COMMISSION (February 14, 1992206 SCRA 283)

JUVENAL LAZAGA, a Research Associate of SEAFDEC-AQD, had filed a complaint for non-payment of separation benefits with the Arbitration Branch of the National Labor Relations Commission (NLRC). SEAFDEC-AQD is 
the Aquaculture Department of an international organization, the Southeast Asian Fisheries Development Centre, organized through an agreement entered into in Bangkok, Thailand on 28 December 1967 by the Governments of Malaysia, Singapore, Thailand, Vietnam, Indonesia and the Philippines, with Japan as the sponsoring agency. In the answer filed by SEAFDEC-AQD, it alleged that the NLRC had no jurisdiction over the case in as much as the SEAFDEC-AQD is an international organization. The Labor Arbiter dismissed this contention of SEAFDEC-AQD and ruled in favour of LAZAGA, ordering in the process the SEAFDEC-AQD to pay LASAGA's claims in full. SEAFDEC brought this case on certiorari to the Supreme Court.

The Supreme Court reversed the ruling of the NLRC saying that SEAFDEC-AQD, being an intergovernmental organization, enjoys functional independence and freedom from control of the State on whose territory its office is located. The Court quoted with approval the Minister of Justice Opinion No. 139, Series of 1984:

"4. One of the basic immunities of an international organization is immunity
from local jurisdiction, i.e., that it is immune from the legal writs and processes
issued by the tribunals of the country where it is found. (See Jenks, [International
Immunities], pp 37-44.) The obvious reason for this is that the subjection of such
an organization to the authority of the local courts would afford a convenient
medium thru which the host government may interfere in its operations or even
influence or control the policies and decisions of the organization; besides, such
subjection to local jurisdiction would impair the capacity of such body to
discharge its responsibilities impartially on behalf of its member-States. In the
case at bar, for instance, the entertainment by the National Labor Relations
Commission of Mr. Madamba's reinstatement case would amount to interference
by the Philippine Government in the management of decisions of the SEARCA
governing board; even worse, it could compromise the desired impartiality of the
organization since it will have to suit its actuations to the requirements of the
Philippine law, which may not necessarily coincide with the interests of the other
member-States. It is precisely to forestall these possibilities that in cases where the
extent of the immunity is specified in the enabling instruments of international
organizations, jurisdictional immunity from the host country is invariably among
the first accorded. (See Jenks, Id; See also Bowett, The Law of International
Institutions, pp. 284-285)."

Anent another issue raised by LAZAGA, the Court also rejected LAZAGA's invocation of estoppel with respect to the issue of jurisdiction as estoppel does not apply to confer jurisdiction to a tribunal that has none over a cause of action. Jurisdiction is conferred by law, the Court added. And where there is none, no agreement of the parties can provide one. 


\section{OPINIONS OF THE SECRETARY OF JUSTICE}

Validity and effectiveness of foreign Court decisions in penal matters.

OPINION No. 2 Series 1992-Regarding the request for official guidelines on the desire of certain Filipinos to serve their sentence in the Philippines after deportation from Canada.

The Secretary of Foreign Affairs requested an opinion regarding official guidelines on the desire of certain Filipinos to serve their sentence in the Philippines after deportation from Canada. Four Filipinos were found guilty of contempt of Court for refusing to testify during the hearing of their co-accused and were each meted a jail sentence of four months. They asked the Philippine Embassy in Ottawa that they be deported to and serve their sentence in the Philippines instead of Canada.

The Secretary, in ruling that there is no sufficient legal basis for the four Filipinos to serve their sentence in the Philippines quoted with approval its previous Opinion on the same subject:

“...

... there is no sufficient legal basis for the Philippine Government to accept the ... transfer. This would in effect require the Philippine Government, not only to recognize, but also to enforce in the Philippines, the judgment of a [foreign] Court in a criminal case. ... we are not aware of any provision in Philippine law authorizing the recognition and enforcement of foreign judgment[s] in criminal proceedings. Under the Revised Rules of Court, only judgments of foreign courts in civil cases, particularly those involving a person or specific thing, may be given effect in the country \{Sec. 50, Rule 39\} ... It (was) concluded that the Philippines would have to pass domestic legislation allowing for prisoners convicted abroad to be transferred to the Philippines to serve sentence and that an agreement would have to be signed to enable such transfers to take place." (Op. No. 80, s. 1986) 


\section{SINGAPORE}

\section{LEGISLATION}

\section{Privileges and Immunities}

\section{The International Organizations (Immunities and Privileges) (APEC Secretariat) Order 1993*}

["APEC" (Asia Pacific Economic Cooperation) was formed on 5 November 1989. Its objective is to identify and remove obstacles to trade and investment among participating countries consistent with the multilateral framework of the General Agreement on Tariffs and Trade. The following countries are participants: ASEAN countries (Brunei, Darussalam, Indonesia, Malaysia, Philippines, Singapore and Thailand), Australia, Canada, Japan, New Zealand, South Korea and United States. China, Hongkong and Taiwan joined in 1991.

There is an annual Ministerial meeting. At the fourth Ministerial Meeting held at Bangkok, 10-11 September 1992, it was decided to form an APEC Secretariat to be based in Singapore. The Secretariat serves as a support mechanism to facilitate and coordinate APEC activities, provide logistical and technical services and administer APEC financial affairs under the direction of the APEC Senior Officials Meeting (SOM). It will be empowered to act on behalf of member countries under the direction of ministers as communicated through the SOM.]

On 12 February 1993, the President of Singapore acting under section 2 of The International Organisations (Immunities and Privileges) Act (Chapter 145) published by order (Gazette Notification No. S25/93) The International Organisations (Immunities and Privileges) Order. This Order confers legal capacity on the Secretariat (Article 3). It will enjoy inviolability of official archives and premises, provided that the Secretariat shall not permit its premises to be used as a refuge in order to avoid due process of law in Singapore, or in any manner incompatible with the purposes of the Secretariat (Article 4). It shall enjoy certain tax reliefs, other than taxes on the importation of goods, but it will not be able to claim exemption from taxes which are charges for public service (Article 5). However, no charges will be levied on the importation of goods used for official purposes (Article 6).

The Executive Director and staff enjoy, while within the territory of Singapore, immunity from personal arrest and from legal process in relation to

* Courtesy of Mr. Foo KIM Boon, Attorney-General's Chambers, Singapore. 
acts done in their official capacity, and while exercising their functions, the like exemption or relief from taxes as will be accorded to an envoy of a sovereign power accredited to Singapore. Such immunity and privileges however do not extend to Singapore citizens or permanent residents working in the Secretariat (Article 8).

\section{THAILAND}

\section{NOTES AND STATEMENTS}

Military exercises in the maritime zones of another state

Note from the Government of Thailand to the Government of Malaysia, 20-21 November 1992*

[The note is in response to Malaysia's announcement of missile live firing exercises in a specified maritime area that intruded into Thailand's maritime zones. The Malaysian authorities immediately apologized, stating that a genuine error had been made concerning the geographical coordinates of the area in question. The correct coordinates were announced, confining the area to Malaysia's own maritime zones, and the date of the exercises changed from 22-29 November 1992 to 25-27 November 1992.

Nevertheless, the present note by the Thai Ministry of Foreign Affairs sets out Thailand's international legal position regarding the controversial issue of military exercises in the maritime zones of another State.]

With reference to the Notice by the Hydrographic Directorate, Royal Malaysian Navy, Number N/S 6163, dated 14 November 1992, stating that missile live firing exercises will be conducted from 22 November to 29 November 1992 in an area bounded by specified coordinates, and that vessels navigating in the vicinity are advised to keep clear of the area, the Ministry of Foreign Affairs wishes to inform the Malaysian side as follows:

1. Since no universally accepted rule of international law specifically prohibits the use by one State of another State's exclusive economic zone for

\footnotetext{
* Courtesy of Dr. Kriangsak Krttichaisaree, Ministry of Foreign Affairs, Bangkok.
} 
military exercises or weapon testing purposes, it might be presumed that such use is not unlawful. But as two-thirds of the area in question are within Thailand's exclusive economic zone, the Thai side would have appreciated being consulted well in advance. The area is not a part of the high seas, but a part of the maritime zone of Thailand and is, moreover, adjacent to the Straits of Malacca, where maritime traffic is particularly dense. The Thai authorities therefore regret this lack of prior consultation.

2. The Thai authorities also regret being informed at such short notice, barely a few days before the intended military exercises.

3. Bearing in mind other lawful uses of the sea in the area, the duration of the scheduled exercises appears to be excessive and unreasonable and would likely cause undue interference with other lawful uses of the sea. According to international practice, missile live firing exercises usually last half a day or, at most, one day. Therefore, the Malaysian authorities are requested to consider reducing the duration of the exercises to the absolute minimum so that other lawful uses of the sea in the area would not be unduly affected.

4. In any case, the Malaysian Navy should take extra care and precaution before and during the exercises so as not to endanger other lawful users of the area.

5. It is the understanding of the Thai Government that should the Royal Thai Navy wish to conduct military exercises in Malaysia's exclusive economic zone at some future time, the Royal Thai Navy would be accorded the same treatment on the basis of reciprocity.

6. It should be noted that part of the northeastern sector of the area encroaches into Thailand's territorial sea and contiguous zone. It is a wellestablished rule of international law that one State cannot conduct military exercises in the territorial sea of another State without the latter's consent. Therefore, notwithstanding paragraphs 1-5 above, the Malaysian authorities are requested to confine the area of military exercises to the maritime area lying beyond Thailand's territorial sea and contiguous zone.

\section{Rights of passage and freedom of navigation}

\section{Statement of the Ministry of Foreign Affairs of Thailand*}

It has been brought to the attention of the Ministry of Foreign Affairs that several States have now enacted laws and regulations, the effect of which is to

\footnotetext{
* UN Doc. A/48/90 Annex (22 Feb. 1993).
} 
restrict the rights of passage and the freedom of navigation of foreign ships in their maritime zones. The Ministry of Foreign Affairs wishes to make known the position of the Royal Thai Government on this matter as follows:

1. According to the well-established rules of customary international law and State practice as recognized and codified by the 1982 United Nations Convention on the Law of the Sea, ships of all States have the right of innocent passage in the territorial sea, the right of transit passage in the straits used for international navigation and the freedom of navigation in the exclusive economic zone of another State.

2. All foreign ships, including warships, merchant ships and fishing vessels, can exercise such rights and freedom without having to give prior notification to, or obtain prior permission, approval or consent from the coastal State concerned regarding their intended passage.

3. Therefore, any laws and regulations which tend to restrict the aforesaid rights and freedom are contrary to the rules of customary international law and are, moreover, incompatible with the obligations assumed by the States concerned when they signed the 1982 Convention.

4. For these reasons, the Royal Thai Government feels obliged to declare that Thailand does not consider herself bound by the laws and regulations in question. In the meantime, it is hoped that States which have enacted such laws and regulations will not actually carry out any measure to impede or interfere in any way with the legitimate exercise by foreign ships of the right of innocent passage in their territorial seas, the right of transit passage in their straits used for international navigation or the freedom of navigation in their exclusive economic zones. 